\title{
Formulation and Evaluation of Herbal Hair Gel Containing Fenugreek Seed Extract for Nourishment and Hair Growth
}

\author{
Suryawanshi Nishant C ${ }^{2}$, Dr. Vijayendra Swamy S.M. ${ }^{1}$, Nagoba Shivappa N. ${ }^{2}$, Wanje Vaijanti V. ${ }^{2}$ \\ 1Principal, Channabasweshwar Pharmacy College, Kava Road, Latur \\ ${ }^{2}$ Channabasweshwar Pharmacy College, Latur, Maharashtra, India \\ Corresponding Author : Dr. Vijayendra Swamy S.M., E-mail: vijayendraswamy@yahoo.com
}

\begin{abstract}
The present study now a days many people face the major problem related to hair i.e. hair loss. There are many causes of hair loss physiological conditions, emotional or physical stress, nutritional deficiencies, hormonal disorders one of the due to hormone deficiency of estrogen. External administration of the estrogen could changes the hormonal cycle and increase cancer risk some natural alternative estrogen therapy can be found in the various plants containing natural products those having weak estrogen activity like Phyto-estrogen. Herbal drug has less side effects and more effective as comparative to synthetic drug. Phytoestrogen are competing with the estrogen by the binding to the estrogen receptor and produce estrogen effect, Phytoestrogen in the fenugreek seed. Family - Fabaceae Ethanolic extract of (Trigonella foenum-graecum) fenugreek seed prepared for the topical formulation of herbal hair gel formulation by using Carbopol 934 gelling agent, glycerin, pvp, methyl paraben, PEG, Triethanolamine Fenugreek was evaluated for its potency on hair growth activity by in vivo method. In vivo, study $2.5 \mathrm{mg}$ of fenugreek extract is used. That is applied on the shaved skin of mice to determine the length of hair and the different cyclic phase of hair follicles like anagen and s phases were will be grow after some time periods. From the study topical use of gel formulation were apply for 30 days .There are use of fenugreek extract containing gel formulation over the shaved skin of mice that shows the significant result by increase the hair growth. The prepared gel was characterized for their physicochemical constants, preliminary phyto-chemical analysis, quantitative analysis, Spread-ability, $\mathrm{pH}$, viscosity, and stability study.
\end{abstract}

Keywords: Fenugreek Seed Extract, Glycerin, Carbopol 934, Hair Growth

\section{INTRODUCTION}

The hair has a protective role against the adverse effect of environment, for example temperature and most important role is the aesthetic purpose and if the hair encounters any abnormalities, the confidence of the person will be disturbed or most common abnormality is a depigmentation (gray-hair), dandruff. Now a day's number of people who had suffered from hair loss or hair thinning problem even baldness also is increasing in world wide. Hair loss is a dermatological disorder and this is the major problem, hair loss is the reduction of hair volume. ${ }^{[1,2]}$ Hair treatment or nourishment is required. To prevent the hair loss or alopecia is a common patient complaint due to psychological and physical distress. By using hair shampoo or conditioner treatment is not possible and not enough to hair growth as well as roots are living cells that need to be nourished in order to stay healthy; therefore, the administration of hair tonic is also required. to treat the such hair loss alopecia hair fall ${ }^{[3]}$ Anti-oxidant present the seeds of 
T. foenum graecum have been very used as anti-lice, anti-dandruff activity as well as hair growth and soothing effects produce, Trigonella foenum-graecum, belonging to family Fabaceae, has been used traditionally for various pharmacological effects, such as anti-diabetic, anti-cancer, anti-fungal, anti-pyretic, and antibacterial [4] ]. The plant contains active constituents such as alkaloids, flavonoids, steroids, Saponins like in steroidal hormones etc. In that vitamins A, B1, C, and nicotinic acid; and $0.015 \%$ volatile oils contains. ${ }^{[5,6,7]}$.

\section{METHODS AND MATERIAL}

Mechanism of action :- A competitive inhibitor of type 2 5-alpha reductase' inhibits the transformation of testosterone to dihydrotestosterone (DHT). Androgen-dependent process in hair loss is predominantly due to the binding of DHT to the androgen receptor. The androgen is sex hormones found in the testosterone and androgens are important to hair growth. Fenugreek seed extract increases testosterone level in the body. In that way hair growth is possibly the hormone-receptor complex activates the genes responsible for the gradual change of large terminal follicles to miniaturized follicles. ${ }^{[8]}$

\section{Formulation}

Hair Gel: - A viscous substance styling hair

Gels are the transparent clear dosage form in which drug can be interrupted in aqueous form.

The gels are form cross linking structure relatively newer class of dosage forms created by entrapment of large amounts of aqueous or hydro-alcoholic liquid in a network of colloidal solid particles, Most topical gels are prepared with polymers such as Carbomers which impart an aesthetically pleasing, clear sparkling appearance to the product and a easily washed off the skin with water.

\section{A. Properties of gel:}

1. The gel should be sterile or clear.

2. The formulation of gel should not be sticky non greasy.

4. The gelling agent should be inert as well as safe.

5. It should not be reacting with other excipients does not decompose the active ingredients.

6. It should be easily spread on to the skin.

7. Entrapped the drug by swelling property $[9,10]$.

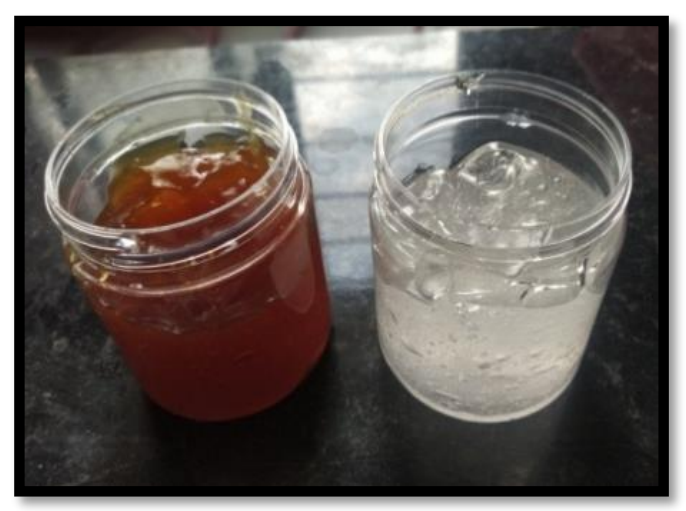

Fig 1. Hair Gel

Preparation of herbal hair gel formulation.

Six different herbal hair gel formulations were prepared by simple gel formulation preparation method. The gel was prepared by using fenugreek seed extract in which carbopol is used as base or gelling agent and other excipients such as methyl paraben as preservative, glycerin as humectant, poly ethylene glycol (PEG)as penetration enhancer , Carbopol 934 as gelling agent, PVP as hair conditioner and Triethanolamine for adjustment of PH. Add Carbopol 934 two percentages and measured quantity of extracts was dispersed in up to $100 \mathrm{ml}$ of distilled water as solvent and mixed by continuously stirring by using magnetic stirrer at $800 \mathrm{rpm}$ for 1 hour. Glycerin $3 \mathrm{ml}$ was added in to the mixture 
under continuous stirring. 5mg PVP, methyl paraben or poly ethylene glycols also add in mixture the mixture was neutralized by drop wise addition of $1 \mathrm{ml}$
Triethanolamine. Mixing was continued until a transparent gel was formed. ${ }^{[11]}$

Table 1. FORMULATION TABLE

\begin{tabular}{|l|c|c|c|c|c|c|}
\hline \multicolumn{1}{|c|}{ Ingredients } & F1 & F2 & F3 & F4 & F5 & F6 \\
\hline Fenugreek extract (g) & 2.5 & 2.5 & 2.5 & 2.5 & 2.5 & 2.5 \\
\hline Carbopol-934 (mg) & 0.5 & 0.8 & 1.1 & 1.4 & 1.7 & 2 \\
\hline PVP (mg) & 5 & 5 & 5 & 5 & 5 & 5 \\
\hline Glycerin (ml) & 3 & 3 & 3 & 3 & 3 & 3 \\
\hline Methyl paraben (mg) & 10 & 20 & 10 & 20 & 10 & 20 \\
\hline PEG (ml) & 6 & 6 & 6 & 6 & 6 & 6 \\
\hline $\begin{array}{l}\text { Triethanolamine } \\
\text { (ml) }\end{array}$ & 1 & 1 & 1 & 1 & 1 & 1 \\
\hline Flavoring agent (q.s) & - & - & - & - & - & - \\
\hline Water (ml) & Up to & $\begin{array}{l}\text { Up to } \\
100\end{array}$ & $\begin{array}{l}\text { Up to } \\
100\end{array}$ & $\begin{array}{l}\text { Up to } \\
100\end{array}$ & $\begin{array}{l}\text { Up to } \\
100\end{array}$ & $\begin{array}{l}\text { Up to } \\
100\end{array}$ \\
\hline
\end{tabular}

\section{A. Preformulation studies:}

Physical characteristic of fenugreek extract ${ }^{[12]}$

Table 2. Preformulation studies

\begin{tabular}{|c|c|c|c|}
\hline $\begin{array}{c}\text { Sr. } \\
\text { No. }\end{array}$ & parameters & $\begin{array}{c}\text { Specification } \\
\text { as per IP } \\
1996\end{array}$ & Result \\
\hline 1 & Appearance & $\begin{array}{c}\text { Yellowish } \\
\text { brown }\end{array}$ & $\begin{array}{c}\text { Yellowish } \\
\text { brown }\end{array}$ \\
\hline 2 & Odour & $\begin{array}{c}\text { Characteristi } \\
\text { c }\end{array}$ & $\begin{array}{c}\text { Characteristi } \\
\text { c }\end{array}$ \\
\hline 3 & Taste & Bitter & Bitter \\
\hline
\end{tabular}

a ) Solubility Study

Table 3. Solubility of fenugreek extract

\begin{tabular}{|c|c|c|}
\hline Sr. No. & Solvents & Result \\
\hline 1 & Methanol & soluble \\
\hline 2 & water & Soluble \\
\hline 3 & Ethanol & soluble \\
\hline 4 & Ether & Insoluble \\
\hline 5 & chloroform & Insoluble \\
\hline
\end{tabular}

\section{b) Ash value:}

Ash value of pure drug was found to be ${ }^{[13]_{-}}$

The percentage of total ash was calculated with reference to air dried sample. 
$=$ Weight of Empty crucible $(\mathrm{A})=16.138 \mathrm{gm}$

$=$ Weight of Drug taken $(\mathrm{B})=1 \mathrm{gm}$

$=$ Weight of dish + drug $(C)=17.137 \mathrm{gm}$

$=$ Weight of dish + ash [after complete the incineration] (D) $=16.219 \mathrm{gm}$

\section{Calculations:}

$$
\begin{aligned}
=\text { Weight of total ash } & =(\mathrm{D})-(\mathrm{A}) \\
& =16.219-16.138 \\
& =0.081 \mathrm{gm}
\end{aligned}
$$

$=1 \mathrm{gm}$ of extracts=weight of total ash

$=100 \mathrm{gm}$ of fenugreek seed extracts=?

$=100 \times$ weight of total ash

1

$$
=\underline{100 \times 0.081}
$$

1

Total Ash Value $=8.1 \%$

\section{c) Acid insoluble:}

Total Acid insoluble Ash $=0.358 \%$

\section{d) Loss on drying:}

The mean loss on drying was found to be $2.90 \%$

\section{e) Bulk density and tapped density ${ }^{[14]}$}

Bulk density = weight of sample/bulk volume

$$
\begin{aligned}
& =10 / 22 \\
& =0.454
\end{aligned}
$$

Tapped density = weight of sample/tapped volume

$$
\begin{aligned}
& =10 / 17 \\
& =0.5882
\end{aligned}
$$

\section{f) Hausner ratio ${ }^{[15]}$}

$$
\begin{aligned}
\text { Hausner ratio } & =\text { Tapped density/Bulk density } \\
& =0.5882 / 0.454 \\
& =1.2955
\end{aligned}
$$

\section{EVALUATION TEST}

\section{a) $\mathrm{PH}$}

The $\mathrm{pH}$ value of herbal hair gel is determining by the $\mathrm{pH}$ meter. The measurement was performed at 1 , 30,60, 90 days after preparation to detect any $\mathrm{pH}$ changes with time.

\section{b) VISCOSITY}

The measurement of viscosity of the prepared herbal hair gel was done by using Brookfield viscometer (model RVTDV II).the reading was taken at $100 \mathrm{rpm}$ using the spindle no.6.

\section{c) APPEARANCE AND HOMOGENECITY}

The prepared gels were tested by physical appearance and homogeneity by visual observation of an herbal hair gel formulation. ${ }^{[16]}$

d) SPREADABILITY: the Spreadability was determined by parallel plate method which is widely used for determining and quantifying the Spreadability of semisolid preparations. Various formulations $(1 \mathrm{~g})$ were pressed between two $20 \times 20$ $\mathrm{cm}$ horizontal plates, the upper of which weighed $125 \mathrm{~g}$. The spread diameter was measured after $1 \mathrm{~min}$. Spreadability was calculated using the following formula:

$$
\mathrm{S}=\mathrm{M} \times \mathrm{L} / \mathrm{T}
$$

Where, $\mathrm{S}=$ Spreadability, $\mathrm{M}=$ Weight in the pan (tied to the upper slide), $\mathrm{L}=$ Length moved by the glass slide and $\mathrm{T}=$ Time (in sec.) taken to separate the slide completely each other. ${ }^{[16]}$

DIFFUSION STUDY : - The diffusion study was important to determine the drug release of prepared herbal hair gel formulation. It carried out such way taken Franz tube in which 1gm of herbal hair gel was taken packed on the bottom with cellophane membrane. Membrane is work as skin. The tube surface is deep in to the solution. $250 \mathrm{ml}$ phosphate 
buffer solution use to absorption media of drug and maintain the $\mathrm{PH} 7.4$ of solution remove the $5 \mathrm{ml}$ sample from the media time to time hours 1 , 2,3,4,5,6,7,8 hours and replace with stock solution then determine drug release at $234 \lambda \max$ of herbal hair gel.[17]

STABILITY STUDY Optimized formulation was subjected to stability as per ICH guidelines at the following conditions (ICH, 2003). It showed No significance change in properties of the optimized formulation \& the drug release. Sufficient quantity of herbal hair gel formulation were packed in stability container and kept in a Stability chamber at Samples were kept in stability chamber at following conditions for 3 months $-1.40 \pm 2^{\circ} \mathrm{C}$ and $75 \pm 5 \% \mathrm{RH}$ (Accelerated temperature)2. Room temperature Formulations were analyzed at 1, 2 and 3 months for following tests- i) Visual appearance ii) Drug diffusion study ${ }^{[18]}$

\section{IN VIVO STUDY}

Healthy 18 albino rat are purchased from Sainath Agencies Hyderabad (India) and used for hair growth promoting activity. The experimental protocol was approved by Institutional Animal ethics committee, (IAEC), and the care of the animals was carried out as per guideline of the Committee for the Purpose of control and Supervision of Experiments on Animals protocol no.

CPCSEA / CBPL / AH-47 /2018-19 Animals were placed in cages and kept in standard environmental conditions, fed with standard diet ad labium and allowed free access to drinking water. They were acclimated 7 days before entry into subsequent study. Experimental animal:-

Wistar rats (150-200 gm) of either sex
Diet and water: - Animals had free access to standard pellet diet and water.

The experimental protocol was approved by institutional animal ethical committee (IACE) and laboratory animals were taken care according to the guideline of CPCSEA, ministry of forest and environment, government of India.

The animals are divided in to three groups each group contain 6 animals as following

Group I - was use as Control

Group II - was use as Standard

Group III - was use as Formulation

\section{Skin irritation Studies}

The Wistar rat of either sex weighing 150-200 g was used for this test. The intact skin was used. The hairs were removed from the rat 3days before the experiment. The gels containing extracts were used on test animal. Gel base was applied on the back of animal taken as control. The animal was treated daily up 24 hour and finally the treated skin was examined visually for erythema and edema. ${ }^{[19,20]}$

1. Hair Length -Hair was plucked randomly from the depilated area with the help of electric clipper and measured the hair length with the help vernier caliper and calculated the mean of hair length. ${ }^{[22]}$

\section{Treatment for hair growth activity in-vivo study:}

In which research study to determine the formulation of fenugreek seed extract hair gel to improve hair growth on the Wistar albino rat. Eighteen Wistar rats are taken in that study. Those 18 rats are divided in to the three groups each group contain six rats. In which first group use as control group. In which Second group standard product use as $2 \%$ minoxidil to evaluate the hair growth to compare with the standard and in third group $2.5 \mathrm{mg}$ 
fenugreek extract containing herbal hair gel formulation. Used for hair growth promoting activity or hair growth. Remove hairs by using electric trimmer from the dorsal portion of rat area $3 \mathrm{~cm}^{2}$ or totally clean skin by using the standard marketed hair remover product veet. This study is 30th day hair growth activity. Shaved area of skin treatment daily applied twice daily to determine the hair growth activity. Observe the increases the hair growth or thickness of hair as well as length. The experimental protocol was approved by the Institutional animal ethics committee. ${ }^{[22.23]}$

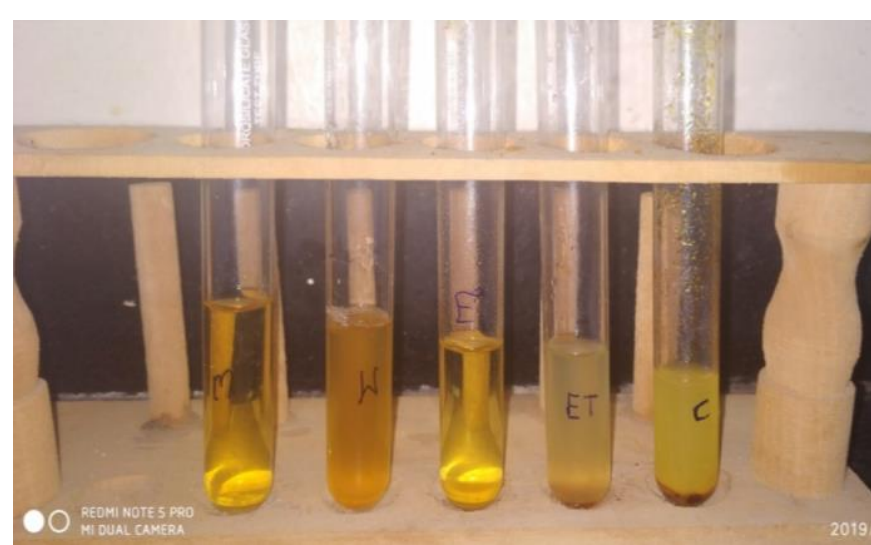

Fig 2.

Interpretation of FTIR Spectra

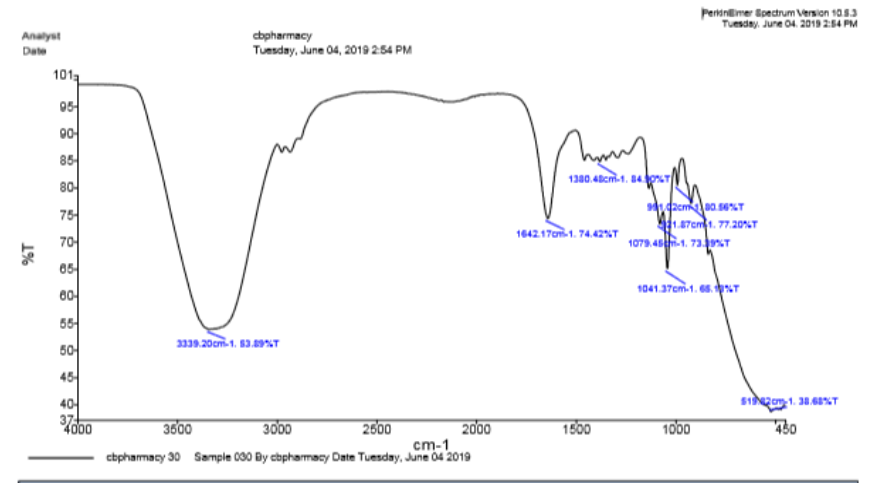

Fig 3. FTIR of Pure Trigonella Foenum Graecum extract

Table 4. Interpretation of fenugreek

\begin{tabular}{|c|l|c|l|}
\hline SR.NO & Functional Group & Standard Frequency & Observed Peak \\
\hline 1 & N-H stretching & $3350-3310$ & 3339.20 \\
\hline 2 & C = O stretching & $1648-1638$ & 1642.17 \\
\hline 3 & O-H bending & $1390-1310$ & 1380.48 \\
\hline 4 & $\begin{array}{l}\text { C-H,C=O,C-H no } \\
\text { stretching }\end{array}$ & $1085-1050$ & 1079.45 \\
\hline 5 & C-O-O-CO`stretching & $1050-1040$ & 1041.37 \\
\hline 6 & C=C stretching & $995-985$ & 991.02 \\
\hline
\end{tabular}


B. Evaluation test of fenugreek herbal hair gel:

Table 5

\begin{tabular}{|c|c|c|c|c|c|c|c|}
\hline $\begin{array}{l}\text { Sr. } \\
\text { No }\end{array}$ & Formulation & Appearance & $\mathrm{pH}$ & $\begin{array}{c}\text { Viscosity } \\
\text { cps }\end{array}$ & Homogeneisity & Spradability & consistency \\
\hline 1 & $\mathrm{~F} 1$ & \multirow{6}{*}{$\begin{array}{l}\text { Yellowish } \\
\text { brown }\end{array}$} & 6.1 & 12300 & \multirow{6}{*}{ Good } & \multirow[t]{2}{*}{ No Good } & \multirow{6}{*}{ Smooth } \\
\hline 2 & F2 & & 5.9 & 17100 & & & \\
\hline 3 & F3 & & 6.7 & 23600 & & \multirow{4}{*}{ Good } & \\
\hline 4 & F4 & & 7.2 & 31831 & & & \\
\hline 5 & F5 & & 5.3 & 42948 & & & \\
\hline 6 & F6 & & 6.6 & 47500 & & & \\
\hline
\end{tabular}

\section{Estimation by UV spectroscopy:}

\section{Calibration of fenugreek seed extract}

Table 6. Calibration of fenugreek seed Extract

\begin{tabular}{|c||c||c|}
\hline Sr.no & Concentration $(\mathrm{ug} / \mathrm{ml})$ & $\begin{array}{c}\text { Absorbance }(\lambda \text { max observed at } \\
\text { 234.nm }\end{array}$ \\
\hline \hline 1 & 2 & 0.258 \\
\hline 2 & 4 & 0.356 \\
\hline 3 & 6 & 0.484 \\
\hline \hline 4 & 8 & 0.593 \\
\hline 5 & 10 & 0.682 \\
\hline \hline 6 & 12 & 0.781 \\
\hline
\end{tabular}

\section{Calibration curve: -}

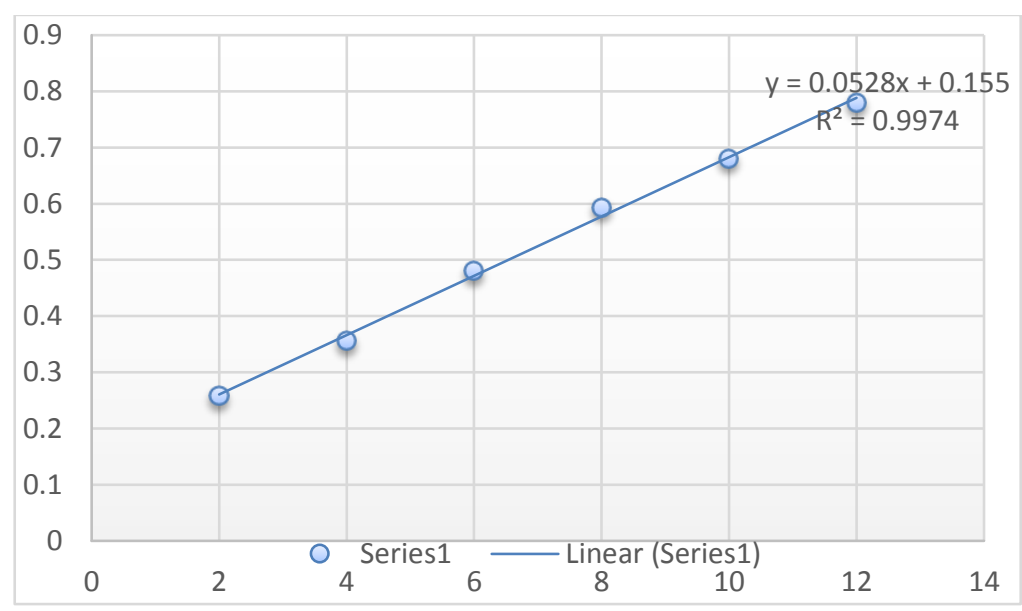

Fig 4. Calibration Curve of fenugreek seed Extract 
D. Diffusion Study:

Table 7. Fenugreek Herbal hair gel

\begin{tabular}{|c|c|c|c|c|c|c|}
\hline \multirow{2}{*}{$\begin{array}{c}\text { Time in } \\
\text { hour }\end{array}$} & \multicolumn{7}{|c|}{ \% OF DRUG DIFFUSION } \\
\cline { 2 - 7 } & F1 & F2 & F3 & F4 & F5 & F6 \\
\hline $\mathbf{0}$ & 0 & 0 & 0 & 0 & 0 & 0 \\
\hline $\mathbf{1}$ & 11.39 & 17.96 & 17.62 & 20.11 & 18.69 & 24.18 \\
\hline $\mathbf{2}$ & 28.16 & 26.56 & 32.18 & 30.12 & 27.19 & 35.76 \\
\hline $\mathbf{3}$ & 39.74 & 32.67 & 44.81 & 49.18 & 34.63 & 48.89 \\
\hline $\mathbf{4}$ & 43.92 & 39.84 & 53.64 & 56.29 & 49.28 & 57.69 \\
\hline $\mathbf{5}$ & 51.49 & 48.17 & 69.37 & 62.84 & 58.71 & 71.23 \\
\hline $\mathbf{6}$ & 68.32 & 65.49 & 76.94 & 79.43 & 77.18 & 84.17 \\
\hline $\mathbf{7}$ & 71.10 & 69.21 & 84.79 & 89.32 & 83.20 & 91.12 \\
\hline $\mathbf{8}$ & 80.11 & 77.26 & 89.44 & 84.54 & 80.68 & 93.14 \\
\hline
\end{tabular}

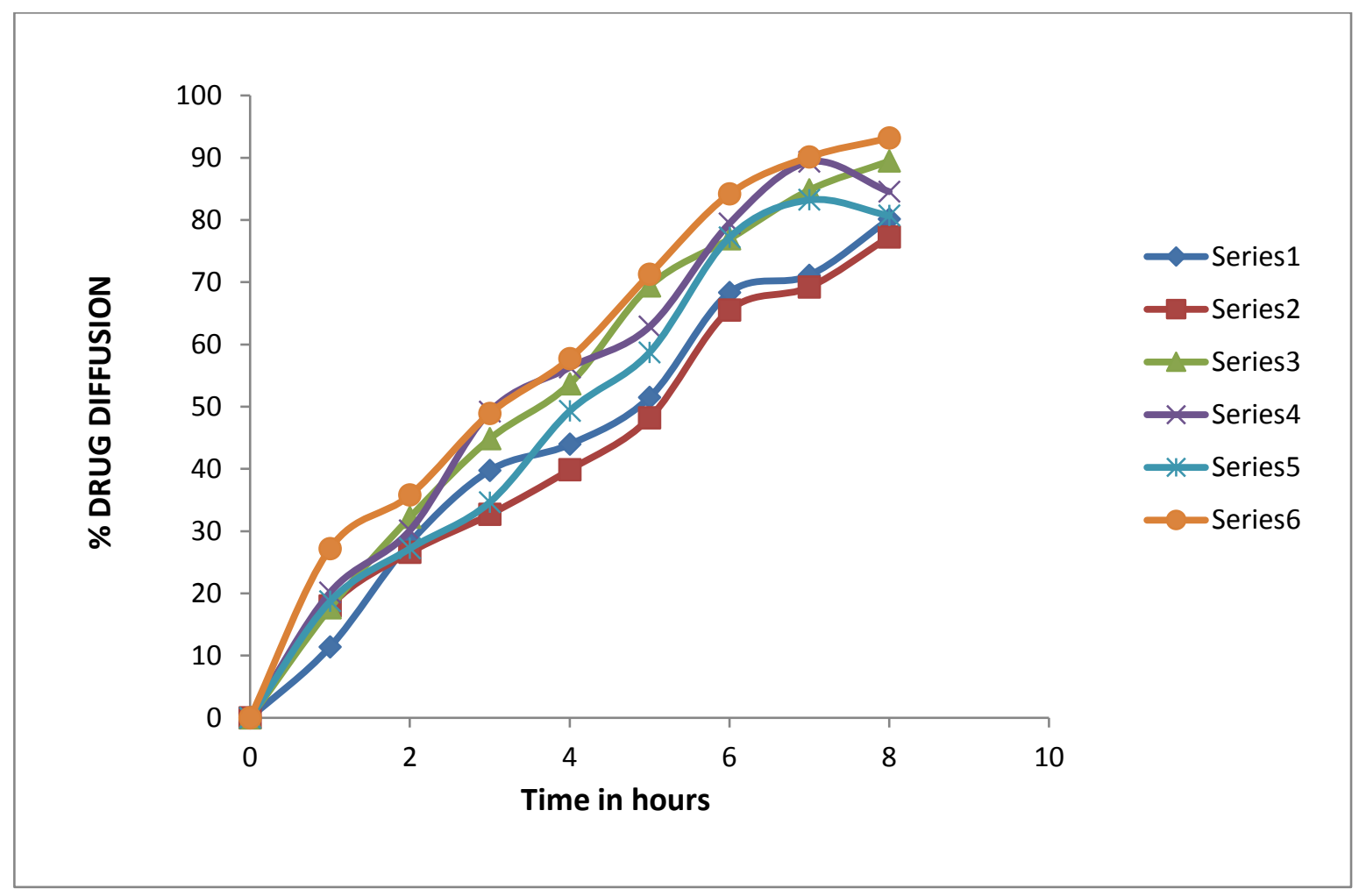

Fig 5. Diffusion study graph 
E. Stability study:

Table 8. Stability study

\begin{tabular}{|c|c|c|c|c|c|c|}
\hline Sr no & $\begin{array}{c}\text { Time in } \\
\text { days }\end{array}$ & $\begin{array}{l}\text { Physical } \\
\text { changes }\end{array}$ & $\mathrm{pH}$ & $\begin{array}{l}\text { Spared- } \\
\text { ability }\end{array}$ & viscosity & consistency \\
\hline 1 & 01 & \multirow{7}{*}{$\begin{array}{c}\text { Yellowish } \\
\text { Brown }\end{array}$} & 7.2 & \multirow{7}{*}{ Good } & 39100 & \multirow{7}{*}{ Smooth } \\
\hline 2 & 15 & & 7.1 & & 42030 & \\
\hline 3 & 30 & & 6.9 & & 45687 & \\
\hline 4 & 45 & & 6.8 & & 47700 & \\
\hline 5 & 60 & & 6.4 & & 51456 & \\
\hline 6 & 75 & & 6.3 & & 55500 & \\
\hline 7 & 90 & & 6.1 & & 56201 & \\
\hline
\end{tabular}

\section{F. Evaluation of Optimize Formula:}

Table 9

\begin{tabular}{|c|c|c|c|c|c|c|c|c|}
\hline Sr .No & $\begin{array}{c}\text { Time in } \\
\text { Hours }\end{array}$ & $\begin{array}{c}\text { \% drug } \\
\text { release } \\
\text { initial }\end{array}$ & $\begin{array}{c}\text { \% drug } \\
\text { release } \\
\text { after 15 } \\
\text { days }\end{array}$ & $\begin{array}{c}\text { \% drug } \\
\text { release } \\
\text { after 30 } \\
\text { days }\end{array}$ & $\begin{array}{c}\text { \% drug } \\
\text { release } \\
\text { after } \\
\mathbf{4 5 d a y s}\end{array}$ & $\begin{array}{c}\text { \% drug } \\
\text { release } \\
\text { after 60 } \\
\text { days }\end{array}$ & $\begin{array}{c}\text { \% drug } \\
\text { release } \\
\text { after } \\
75 \text { days }\end{array}$ & $\begin{array}{c}\text { \% drug } \\
\text { release } \\
\text { after 90 } \\
\text { days }\end{array}$ \\
\hline 1 & 00 & 00 & 00 & 00 & 00 & 00 & 00 & 00 \\
\hline 2 & 1 & 24.18 & 24.08 & 23.93 & 23.86 & 23.72 & 23.67 & 23.60 \\
\hline 3 & 2 & 35.76 & 35.67 & 35.59 & 35.48 & 35.40 & 35.31 & 35.26 \\
\hline 4 & 3 & 48.89 & 48.71 & 48.63 & 48.56 & 48.44 & 48.38 & 48.21 \\
\hline 5 & 4 & 57.69 & 57.58 & 57.41 & 57.35 & 57.29 & 57.18 & 57.02 \\
\hline 6 & 5 & 71.23 & 71.11 & 70.90 & 70.82 & 70.73 & 70.61 & 70.44 \\
\hline 7 & 6 & 84.17 & 83.00 & 83.88 & 83.73 & 83.60 & 83.39 & 83.22 \\
\hline 8 & 7 & 91.12 & 90.88 & 90.70 & 90.58 & 90.49 & 90.41 & 90.22 \\
\hline
\end{tabular}

\section{G. IN VIVO STUDY}

Skin irritation test:

Does not found or observed any rashes or redness on the skin where applied Herbal hair gel formulation. 
Hair length determination

Table 10.

\begin{tabular}{|c|c|c|}
\hline Groups for 10 Day & Formulation & Hair growth in $\mathbf{m m}$ Mean \pm S.D) \\
\hline Group I & Control & $2.2 \pm 0.1 .5$ \\
\hline Group II & 2\% minoxidil & $5.1 \pm 0.5$ \\
\hline Group III & Herbal hair gel & $4.0 \pm 0.4$ \\
\hline
\end{tabular}

Table 11

\begin{tabular}{|c|c|c|}
\hline Groups for 20 Day & Formulation & Hair growth in $\mathbf{m m}$ (Mean \pm S.D) \\
\hline Group I & Control & $5.9 \pm 0.25$ \\
\hline Group II & 2\% minoxidil & $9.7 \pm 0.20$ \\
\hline Group III & Herbal hair gel & $7.5 .1 \pm 0.35$ \\
\hline
\end{tabular}

Table 12

\begin{tabular}{|c|c|c|}
\hline Groups for 30 Day & Formulation & Hair growth in $\mathbf{m m}(\mathrm{Mean} \pm$ S.D) \\
\hline Group I & Control & $8.3 \pm 0.31$ \\
\hline Group II & 2\% minoxidil & $14.3 \pm 0.31$ \\
\hline Group III & Herbal hair gel & $12 . .4 \pm 0.41$ \\
\hline
\end{tabular}

H. Observation table:

Table 13

\begin{tabular}{|l|l|l|l|}
\hline SR. NO & $\begin{array}{c}\text { Group I } \\
\text { control }\end{array}$ & $\begin{array}{c}\text { Group II } \\
\text { minoxidil }\end{array}$ & $\begin{array}{c}\text { Group III } \\
\text { formulation }\end{array}$ \\
\hline 0 Days & & & \\
\hline 10 Days & & & \\
\hline 20 Days & & & \\
\hline 30 Days & & & \\
\hline
\end{tabular}




\section{DISCUSSIONS}

In the present study the work was attempt to carry out the standardization and extraction of active constituents of fenugreek seed extract and it Also formulate and evaluate Fenugreek herbal hair gel. Fenugreek seed extract was evaluated for physicochemical and phyto-chemical analysis by using different organic solvents. Standardization of fenugreek extract was done with total Ash value, acid insoluble ash loss on drying, Bulk density Hausner ratio etc. Phytochemical analysis was performed on different extracts confirmed the presence of alkaloids, glycosides, triterpenoid, saponins, tannins, flavonoids, etc. The presence of active constituents was also confirmed by the calibration curve of fenugreek seed extract. Formulation of herbal hair gel was done by varying drug concentration of ingredients as F1-F6. Methyl paraben was used as preservative or polyvinyl pyrrolidone as a plasticizer, Triethanolamine use as $\mathrm{pH}$ adjuster in of formulation. All formulations were checked for $\mathrm{pH}$, viscosity, Spreadability, homogeneity. The FTIR studies revealed that, the formulated product is a mixture of drug and the polymers used but not the reaction product with the excipients used. From the above result it can be concluded that the prepared herbal hair gel shows significant hair growth activity.

\section{VI.CONCLUSION}

The fenugreek seed extract shows the significant effect on hair growth process compared with a $1 \mathrm{ml}$ minoxidil it give results positive optimal concentration of $2.5 \mathrm{mg}$. Fenugreek seed extract on the skin did not cause any irritation. Fenugreek containing flavonoids and triterpenoid possess hair growth promoting activity by increases blood circulation to nourish the hair follicles and there by promoting hair growth as well as testosterone level increases in body. The androgenic alopecia also reduce due to fenugreek contain hormones booster.

\section{VII.REFERENCES}

[1]. Arakawa T, Emoto K, Utsunomiya S, Hagiwara Y, Shimizu T (1962) Effect of Swertinogen in hair growth with special reference to its activities on skin function. Tokushima J Exp Med 9 : 3759.

[2]. Adhirajan N, Ravikumar T, Shanmugasundaram N, Babu M (2003) In vivo and in vitro evaluation of hair growth potential of Hibiscus rosasinensis Linn. J Ethanopharm 88(2-3): 235239.

[3]. Wasitaatmadja, S. M., (1997). PenuntunIlmuKosmetikMedik,-Cetakan I. 202 211, Universitas Indonesia Press,

[4]. Didarshetaban, M.B., Pour, S. and Reza, H., 2013.Fenugreek (Trigonellafoenum-graecum L.) as avaluable medicinal plant. Int. J. Adv. biol. biomed.Res., 1: 922-931.

[5]. Turner DJ. Natural product source material use in the pharmaceutical industry: the Glaxo experience. J. Ethnopharmacol. 1996; 51: 39-43.

[6]. Baerheim Svendsen A, Scheffer JJ. Natural products in therapy. Prospects, goals and means in modern research. Pharm. Wkly. [Sci.]. 1982; 4: 93-103

[7]. Mehrafarin A., Qaderi A., Rezazadeh Sh., Naghdi Badi H., Noormohammadi Gh., and Zand E., 2010. Bioengineering of Important Secondary Metabolites and Metabolic Pathways in Fenugreek (Trigonella foenumgraecum L.). J. of Medicinal Plants, 9(35): 1-18.

[8]. Price VH (2003) Androgenetic alopecia in women. J Investig Dermatol Symp Proc 8: 2427.

[9]. Loyd VA., et al. "Ansel's pharmaceutical dosage forms and drug delivery systems. 9th ed. 
Philadelphia: Lippincott Williams \& Will dns; (2011).

[10]. Ofner CM., et al. "Encyclopedia of Pharmaceutical Technology". Informa Healthcare (2007): 1875-18917. T Regupathi, Formulation and Evaluation of Herbal Hair Gel for Hair Growth Potential, Journal of Pharmacology \& Clinical Research Feb, 2017:Vol2, Issue 2. 001008.

[11]. T Regupathi, Formulation and Evaluation of Herbal Hair Gel for Hair Growth Potential, Journal of Pharmacology \& Clinical Research Feb, 2017:Vol2, Issue 2. 001008.

[12]. Rashmi yadav, the health benefits of trigonella foenum-graecum: a review, international journal of engineering research and applications(IJERA) www.ijera.com,Vol.1, Issue 1, pp.032-035

[13]. Agrawal R.S. Physico-Chemical Properties of Fenugreek (Trigonella Foenum - Graceum L.) Seeds, October 2015 IJLTEMAS Volume IV, Issue X, ISSN 2278 - 2540

[14]. Pabon, C.V., P. Frutos, J.L. Lastres and G. Frutos, th and 1992. In-vitro study of mixed controlled release matrix tablets containing HPMC and polyamide., Drug Development and Industrial Pharmacy,. 18(20): 2163-71.

[15]. Agrawal R.S. Physico-Chemical Properties of Fenugreek (Trigonella Foenum - Graceum L.) Seeds, October 2015 IJLTEMAS Volume IV, Issue X, ISSN 2278 - 2540

[16]. Garg A, Aggarwal D, Garg S, Singla AK. Spreading of semisolid formulations: An update. Pharm. Tech. 2002; 84-105

[17]. Yamaguchi Y, Sato H, Sugibayashi K, Morimoto Y. Drug release test to assess quality of topical formulations in japenese market. Drug Dev. Ind. Pharm. 1996; 22(7):569-77.

[18]. Praveen s. Patil , development and evaluation of Anti-dandruff hair gel, international journal of research in pharmacy and chemistry, ijrpc 2011, 1(4) praveen et al Issn: 2231:2781

[19]. Roy RK, Mayank T, Dixit VK, Effect of Citrus coclocynthis schrad, on hair growth activity of albino rat. Australian Journal of Medical Herbalism 2007. http://findarticles.com/p/articles/mi_6801/is_2_ 19/ai_n 28492070/

[20]. Uno H, Kurata S, 1993. Chemical agents and peptides affect hair growth. Journal of Investigative,Dermatology101:

143-147. http://www.nature.com/jid/journal/v101/n1s/ab s/56115 74a.html

[21]. Jegan $N$, hair growth promoting activity of benincasa hispida on androgen induced alopecia animal models, world journal of pharmacy and pharmaceutical sciences, 5 sep 2014, volume , issue 1 10, , 631 -637.

[22]. Mithal BM, Shah RN, 2000. A Hand Book of Cosmetics, 1 Ed, Delhi, Vallabh Prakashan publications. ISBN: 13-978-8185731223

[23]. Tortora GJ, Grabowski SR, 1996. Principles of Anatomy and Physiology. Harper Collins Publishers, Menlopark, California, pp: 129.

\section{Cite this article as :}

Suryawanshi Nishant C, Dr. Vijayendra Swamy S. M., Nagoba Shivappa N., Wanje Vaijanti V., "Formulation and Evaluation of Herbal Hair Gel Containing Fenugreek Seed Extract for Nourishment and Hair Growth", International Journal of Scientific Research in Science and Technology (IJSRST), Online ISSN : 2395-602X, Print ISSN : 2395-6011, Volume 6 Issue 4, pp. 92-103, July-August 2019. Available at doi : https://doi.org/10.32628/IJSRST196416 Journal URL : http://ijsrst.com/IJSRST196416 